\title{
The Case of Correlatives: A Comparison between Natural and Planned Languages
}

\author{
Federico Gobbo \\ University of Insubria
}

\begin{abstract}
Since the publication of Volapük, the most important functional and deictic words present in grammar-interrogative, relative and demonstrative pronouns, and adjectives among others - have been described in planned grammars in a series or a table, namely "correlatives," showing a considerable level of regularity. This article compares the degree of regularity in the correlatives series of International Auxiliary Languages (IALs) with the correlative series of natural languages of the world - e.g., with a special attention English, French, German, and Latin, i.e., the languages that influenced directly the most important IALs, from Volapük (1879) to IALA's Interlingua (1951). Moreover, some examples in languages not belonging to the Standard Average European (SAE) sprachbund are presented for control. Finally, the correlatives of Klingon and $\mathrm{Na}$ 'vi, two languages planned in recent times, not for auxiliary but for fictional purposes, are presented by contrast. The
\end{abstract}

Federico Gobbo

Centro di Ricerca "Informatica Interattiva" - via Mazzini 5 - IT- 21100 Varese

Phone 0039-3455135665; Email: federico.gobbo@uninsubria.it

Received July 22, 2011; Revised September 10, 2011; Accepted September 15, 2011. 
main result of this comparison is that, in the case of correlatives, some natural languages are surprisingly far more regular than their planned daughters, in spite of the fact that regularity was a major claim of the efforts in planning IALs during the late XIX and early $\mathrm{XX}$ centuries in Europe.

Keywords: correlatives, volapük, esperanto, interlingua, regularity, language planning, planned language

\section{Introduction}

Human languages - natural and planned languages - are the results of two forces: the natural ability of the human species of acquiring one or more tongues from the society where they grow up, and the results of language planning acts, performed by the society itself. Even if no sharp distinction between ethnic and planned languages can be easily found, because any human language can be put in a continuum between naturalness and artificiality, as argued by Schubert (1989), nonetheless, the dichotomy "natural vs. planned" languages is still useful. ${ }^{1}$

In the case of planned languages, the language planning force is stronger than in natural languages, especially in the beginning. In fact, what distinguishes planned languages from natural one is the presence of a man, ${ }^{2}$ who acts as a language planner - rarely, there is a committee, but even so with a clear leader who takes the final decisions about the structure of the planned language.

1 The expression "artificial language" should be avoided in the English language, as it can be misleading. In fact, unlike many Romance languages, such as French, Italian or Spanish, English does not have a word apart for human languages (French: langue), and a word for languages in general (French: langage; see Lyons 1981: 3). So, it is better to consider "artificial languages" non-verbal languages, i.e., sign systems constructed for specific purposes, e.g., in mathematics, logic, or computer science.

2 Most language planners are men, while women are rare (Yaguello 2001). 
In practice, the language planner publishes a written text, where the structure of the language - usually a basic grammar, core lexicon, and a set of examples - is proposed to the world through a book (or a web site, in recent times, see Gobbo 2005a), so to create a community of supporters and eventually speakers. When published and started to be actually used by a speech community, planned languages enter their "semiological life," as put by Ferdinand de Saussurre (Gobbo 2009), and they follow the laws of evolution common to natural languages. In that case, the structure cannot be changed any further, without reactions and sometimes backlash by the members of the community (Gobbo 2008, 2009). Therefore, the only relative universal not respected by planned languages is the "historical priority of speech over writing" (Lyons 1981: 12). ${ }^{3}$

The diamesic axis (spoken and written actual usage) is helpful to understand the sociolinguistic dimension of planned languages. In fact, very few planned languages achieve the result to be actually spoken by a community. For this reason, planned languages can be usefully ordered in a continuum along the diamesic axis. In particular, Blanke (1985) proposes a scale where to put planned languages following their sociolinguistic success, i.e., the presence and importance of a speech community; this scale starts from "project" (no speech community) until "language" (stable speech community, with presence of family language). ${ }^{4}$

Why people decide to plan a language ex novo? Purposes can be very different. Traditionally, interlinguistics as defined by Jespersen (Gobbo 2008) is the study of planning International Auxiliary

3 In order to relativize the distance between natural and planned languages, Lyons (1991: 69-71) calls the latter Quasi-Natural Languages (QNLs).

4 The only true case for Blanke (1985) is Esperanto; a different analysis is in Gobbo (2005b). The family variety of Esperanto spoken in multilingual families -monolingual Esperanto speakers simply do not exist-is not substantially different from the standard register (Lindstedt 2006). 
Languages (IALs), i.e., languages to be used for spoken and written communication within speakers having different native tongues. Nonetheless, languages can be planned for other purposes too. Bausani (1974) was the first scholar to notice that the process of planning a language for auxiliary purpose was not so different from planning a language for religious, literary or ludic purposes. Bausani's example of language planned for religious purposes is Balaibalan, emerged within the Sufi tradition, one of the few languages planned outside Europe, while Markuska was planned for ludic purposes by Bausani himself as a child (Bausani 1974, Gobbo 1998).

More recent examples of languages planned for non-auxiliary purposes can be found, in particular for literary of fictional ones. For example, Klingon and Na'vi share a lot of characteristics: both were planned as an important part of the background for the sciencefiction universes, respectively for the Star Trek saga (see at least Okrand 1992) and James Cameron's blockbuster movie Avatar (see at least Frommer 2009).

Purpose is not the only criterion that can be used to classify languages. Basing on Bausani (1974), Gobbo (2008) finds another criterion beyond purpose in order to classify planned languages: publicity, i.e., the dichotomy exoteric vs. esoteric. Bausani's example of esoteric language is again Balaibalan; another example of a secret language is the pseudo-Sanskrit spoken in trance (glossolalia) by Hélène Smith, a famous spiritist medium, living in Geneva in Ferdinand de Saussure's times (Giacomelli 2006). Nonpublic languages differ from public ones as readers (or, less often, listeners) can access texts or discourses produced in the secret language without any explicit key to decode them, e.g., a grammar, a bilingual text or a dictionary provided by the language planner. Most secret languages are fascinating exactly because they lack transparency, even if they are well rooted in natural languages - for instance, Tolkien's languages are directly influenced by the languages 
studied by the English philologist, as shown by Solopova (2009).

In general, IALs are public, as their more or less explicit aim is to build a stable speech community. Language planners quite often claim that their language is "easy" to learn, compared to competing IALs - and, of course, natural languages. This claim is based on the regularity of structure of IALs: the aim of regularity is that learners acquire a reasonable level of passive and active proficiency quickly and efficiently. But easiness is hardly acceptable as a linguistic dimension: how to measure it? Even if the claim of "easiness" as so is not acceptable, this property of IALs and planned languages in general can be split up in two different dimensions quite used in linguistics: regularity and similarity.

Regularity is an internal or intralinguistic dimension: no language is completely suppletive, i.e., there are always paradigms that form common transformations in a regular way, which are valid in most cases. For instance, the transformation 'singular-plural of nouns' in English is often rendered through the suffix $-s$. Nonetheless, this rule is not always valid: there are exceptions, or, better said, less productive rules for the same function. IALs try to generalize regularity so that there should be a one-to-one correspondence between rules and transformations. For example, the transformation 'singular-plural of nouns' should be rendered only with one rule, i.e., always valid, without exceptions.

Regularity is counterbalanced by the other dimension present in IALs, that is similarity. Similarity is an external or interlinguistic dimension: the IAL should have a considerable degree of similarity to the lexicon and writing system of the "source languages," i.e., natural languages taken as models for planning, so that learners can take advantage from their language repertoire in becoming familiar with the proposed IAL without extra effort. ${ }^{5}$ Of course, the great

5 To the extent of author's knowledge, the first language planner who clearly described regularity and similarity as two distinct dimensions is de Wahl (1928). 
problem in similarity stays in the choice of the source languages. In fact, this choice highly influences the final structure of the IAL. Bausani (1974) notes that the core features of IALs - in particular phonetics and phonology - are determined by the language repertoire of the language planner, who often chooses unconsciously the sounds belonging to his mother tongue as distinctive features for the phonemes of the IAL. ${ }^{6}$ Hence, the creativity in planning an IAL is not without limits.

A key area of testing the quality of the structure of IALsstretched between regularity and similarity-is the set of functional words dedicated to link clauses together, so that IAL users can build not only simple sentences but also complex texts. In particular, since the publication of Volapük first (1879) and then Esperanto (1887), the most important functional and deictic words - among the others: interrogative, relative and demonstrative pronouns, and adjectiveshas been described in IAL grammars in series or tables, usually called "correlatives," showing a considerable level of regularity.

The aim of this paper is to test the level of regularity in IALs compared to their source languages on one side, and ludic planned languages and typologically distant natural languages on the other side, for control.

\section{Correlatives in Natural Languages}

Correlatives comprehend interrogative clauses and their answers, as well as their relative counterparts. There is a relation between interrogative and relative clauses which is cognitive before linguistic (Gobbo \& Benini 2011). Interrogative forms can be divided in two classes: the first class is made by yes/no questions-including negative questions - while the second class is made by all other

\footnotetext{
6 This phenomenon is called "Bausani's effect" in Gobbo $(2008,2009)$.
} 
questions, in English usually called wh-words, that can be used to introduce interrogative and relative clauses.

(1) a. Who bought the book for the girl? The man.

b. The man [who bought the book for the girl]

The answer to (1a) cannot be yes or no, but should indicate someone who has the power or possibility of buying. The relative clause (1b) shows how the interrogative clause and its answer (1a) can be transformed in a complex sentence. The function of whwords is to modify or substitute an actant, typically a noun, but also the whole predication, in a way similar to adverbs. Tesnière (1959) proposes a typology of grammar characters applied to syntagms which have been elaborated by Gobbo \& Benini (2011) in the form of constructive adpositional grammar, that can be useful to classify the function and meaning of correlatives.

Table 1. Grammar Characters According to Tesnière (1959)

\begin{tabular}{|l|l|l|l|l|}
\hline \multicolumn{1}{|c|}{ Symbol } & \multicolumn{1}{c|}{ O } & \multicolumn{1}{c|}{ A } & \multicolumn{1}{c|}{ E } & \multicolumn{1}{c|}{ I } \\
\hline Conventional name & stative & adjunctive & circumstantial & verbant \\
\hline $\begin{array}{l}\text { Corresponding English } \\
\text { grammar categories }\end{array}$ & $\begin{array}{l}\text { nouns, } \\
\text { pronouns }\end{array}$ & $\begin{array}{l}\text { adjectives, } \\
\text { determiners }\end{array}$ & $\begin{array}{l}\text { adverbs, } \\
\text { adverbials }\end{array}$ & $\begin{array}{l}\text { verbs, } \\
\text { interjections }\end{array}$ \\
\hline
\end{tabular}

Tesnière's (1959) grammar characters are very general: they can be applied to any morpheme of group of morphemes of any language, regardless of the cultural tradition of its normative grammars - in particular, avoiding the risk to apply standard grammar categories belonging to SAE. ${ }^{7}$

In the sequel, Tesnièrian grammar characters will be used in order

${ }^{7}$ In a completely independent way, the same grammar characters are found in Whorf (1945), who tried to avoid this problem in describing grammars of languages belonging to non-SAE sprachbunds. 
to classify the meaning of correlatives. In particular, with the important exception of the verbant character (I), correlatives can take any grammar character: adjunctive (A), stative (O) or circumstantial (E).

If $w h$-words modify actants, they will be adjunctives (A). Comrie (1989: 155) shows how wh-adjunctives work in English:

(2) a. The book [which the man bought for the girl]

b. The girl [for whom the man bought the book]

c. The boy [whose book the man bought for the girl]

English $w h$-adjunctives show a high degree of freedom in (1b) and (2a-c). The correlative English word what is, under a cognitive perspective, the substitution of an actant. In fact, it cannot be used as a relative clause, i.e., a $w h$-adjunctive, but rather as an interrogative (3a-b).

(3) a. What did the man buy for the girl? The book.

b. *The book [what the man bought for the girl]

Henceforth, the grammar character of what will be stative, because it substitutes an actant (Tesnèrian sign: $\mathrm{O}$ ).

Correlatives can also modify the circumstance of the whole predication, like adverbs (4), and for this reason their grammar character will be called circumstantial (E).

(4) a. When will the man buy the book? Later.

b. The man will buy the book [later].

c. The man will buy the book [when he will come].

The normative grammars of languages belonging to the Standard Average European (SAE) sprachbund were influenced by Latin grammar, so circumstantial correlatives will be ordered in the 
following way along their meaning: temporal (tempus), causal (causa), modal (modus), locative (locus). In English circumstantial wh-words are respectively; when, why, how, and where.

Table 2 (below) shows that there is a considerable degree of regularity in the $w h$-words of English, German, French, and Latin, the most influencing natural languages in planning IALs, as said previously. In particular, the prefixes $w h-, w$-, and $q u$ - derive from the Proto-Indo-European prefix $* k^{w}$-: traces can be also found in other languages belonging to the SAE sprachbund, like Greek, Farsi, and other Hindo-European languages (Lehmann 1952, 1974).

Table 2. Wh-Words in English, German, French, and Latin

\begin{tabular}{|c|l|l|l|l|}
\hline Type/language & English & German & French & \multicolumn{1}{|c|}{ Latin } \\
\hline Persona (A) & $\begin{array}{l}\text { who, } \\
\text { which }\end{array}$ & wer & $\begin{array}{l}\text { qui, } \\
\text { quel }\end{array}$ & $\begin{array}{l}\text { quis, } \\
\text { qualis }\end{array}$ \\
\hline Factum (O) & what & was & quoi & quid \\
\hline Tempus (E) & when & wann & quand & quando \\
\hline Causa (E) & why & warum & pour quoi & quare, cur \\
\hline Modus (E) & how & wie & comment & quomodo \\
\hline Locus (E) & where & wo & où & ubi \\
\hline
\end{tabular}

However, regularity in natural languages is only a tendency: for instance in French, the causal correlative is rendered through an analytical strategy, which put together the factual quoi (what) and the preposition pour (for); a similar strategy is also attested in the English what for (5a), while German borrows from the locative in order to fit the same function need (lit. wofür stands for 'where-for,' $5 b)$.

(5) a. What for do you need that?

b. Wofür brauchst du das? 
This tendency in regularity among correlatives is found not only in questions, but also in correlative answers: "One could say that the indefinite, demonstrative, interrogative, universal and negative pronouns, adjectives, and adverbs form the same type of system" (Libert 2008: 92-93).

Correlative answers fill the language need of encoding deixis, i.e., the common ground and mutual knowledge to the actantial act present in the joint attentional frame. Such learning is crucial in the ontogenetic construction of human languages (Tomasello 2003).

Even if it is hardly surprising that a relation exists between correlative questions and answers, this fact was rarely put in evidence. ${ }^{8}$ As far as the author knows, there is only one theoretical framework which made use of it for the purposes of Second Language Acquisition. This framework, developed in Germany within the University of Paderborn, is called Sprachorientierung, i.e., "Language Orientation." Within this framework, correlative prefixes are signed conventionally with the symbols illustrated in Table 3.

Table 3. Symbols for Correlative Prefixes

\begin{tabular}{|c|c|c|c|c|}
\hline Questions & Demonstratives & Indefinites & Universals & Negatives \\
\hline$?$ & $\rightarrow$ & $\exists$ & $\forall$ & $\nexists$ \\
\hline
\end{tabular}

In particular, Frank \& Lobin (1997) show that demonstratives $(\rightarrow)$ form a paradigm with correlative questions in English and German, while in French and Latin this relation is not morphologically evident.

8 Two notable exceptions are Collison \& Morris (1937) and Szerdahelyi (1989).

9 The most complete description of Language Orientation is in Frank \& Lobin (1997). A discussion of its main results is in Maxwell (1988). 
Table 4. Demonstratives in English, German, French, and Latin

\begin{tabular}{|c|l|l|l|l|}
\hline Type/language & English & German & \multicolumn{1}{|c|}{ French } & Latin \\
\hline Persona (A) & that & der & ce & ille \\
\hline Factum (O) & that & das & celui-là & id \\
\hline Tempus (E) & then & dann & alors & tunc \\
\hline Causa (E) & because & darum & parce que & cur \\
\hline Modus (E) & so & so & ainsi, comme ça & ita, sic \\
\hline Locus (E) & there & dort, da & ici, là & ibi \\
\hline
\end{tabular}

Table 4 illustrates the regularity of demonstratives in the most important source languages of the IALs that will be analyzed later. In particular, regularity in correlative questions is partially preserved in English and German demonstratives - for example, in German the question prefix $w$ - can be substituted with the prefix $d$ - in order to obtain most demonstratives of the series. Other regularities can be found if we consider the deictic dichotomy "proximal vs. distant," 10 e.g., English there vs. here, Latin tunc vs. nunc (then vs. now), and so on.

The claim by Frank \& Lobin (1997) of the presence and importance of regularities in natural languages seems to be reasonable in our context. Even if their analysis is limited to Western languages, it is worth noticing that regularity in correlatives is not confined in natural languages belonging to the SAE sprachbund, but, on the contrary, it is a tendency found in many natural languages of the world.

${ }^{10}$ Even if there are natural languages which have three values on the linear spatial axis, i.e., proximal vs. medial vs. distant, most IALs have a two-way system. Perhaps this is due to the interlinguistic criterion of similarity: most "source languages" of the IALs considered in this paper have a two-way system as well. 
Table 5. Wh-Words in Some Languages not Belonging to SAE

\begin{tabular}{|c|l|l|l|l|}
\hline Type/language & Indonesian & Turkish & Japanese & Kiswahili \\
\hline Persona (A) & $\begin{array}{l}\text { yang mana } \\
\text { siapa }\end{array}$ & $\begin{array}{l}\text { hangi, } \\
\text { kim }\end{array}$ & dono & ambaye \\
\hline Factum (O) & apa & ne & dore & nini \\
\hline Tempus (E) & kapan & $\begin{array}{l}\text { ne } \\
\text { zaman }\end{array}$ & itsu & wakati \\
\hline Causa (E) & mengapa & $\begin{array}{l}\text { niye, } \\
\text { neden, } \\
\text { niçin }\end{array}$ & doshite & kwa nini \\
\hline Modus (E) & betapa & nasil & dochira & jinsi gani \\
\hline Locus (E) & dimana & nere & doko & ambapo \\
\hline
\end{tabular}

Table 5 shows that Indonesian and Kiswahili have two competing systems more or less integrated, while Japanese shows a paradigmformed with prefix $d o-$ - which is as regular as the German one.

In sum, the analysis of correlatives in natural languages shows that their regularity is a clear tendency; even more importantly, each correlative word can be split in two morphemes, where the first one-usually the prefix - indicates its type (e.g., question, or demon-strative, all presented in Table 3) while the other indicates its grammar character (e.g., stative, or circumstantial, see again Tables 2, 4, and 5).

In the following, the regularity of correlatives in the most significant planned languages - in particular the presence of types and grammar characters-will be compared with the natural languages analyzed until here. It is worth remembering that planned languages consider not only regularity as a guideline, but also similarity to their source languages, as shown in the Introduction. 


\section{Correlatives in Volapük and its Daughters}

The sociolinguistic relative success of Volapük at the end of the XIX century in Europe (Golden 1997) largely influenced other language planners-Zamenhof included, especially in his protoEsperanto proposed in 1881 (Waringhien 1959, Tresoldi 2011). Schleyer, Volapük's inventor and owner, largely considered the dimension of regularity more important than the similarity with any natural language, ${ }^{11}$ and correlatives are no exceptions. In particular, in Volapük the lexicon is largely monosyllabic, for a claimed perfection of the Chinese language, in vogue at that times. Couturat \& Leau (1903) present demonstratives in Volapük with translations in French and Latin, while English was added in Table 5 (below) for more clarity. In spite of Schleyer's claim of regularity, there is no clear cue to understand the choice of a vowel instead of another.

Table 6. Demonstratives in Volapük and Control Languages

\begin{tabular}{|c|c|c|c|}
\hline Volapük & French & English & Latin \\
\hline at & celui-ci & this & hoc \\
\hline et & celui-là & that & id \\
\hline it & même & same & ipse \\
\hline ot & le même & the same & idem \\
\hline ut & celui & that & qui \\
\hline som & tel & such & talis \\
\hline votik & autre & other & alius \\
\hline
\end{tabular}

${ }^{11}$ According to many scholars, this fact was a key factor in the fall of the Volapukist movement and the rise of the Esperantist movement (see Forster 1982, Large 1985). 
It is hardly surprisingly that volapukists tried to propose direct reforms of the language, in order to get it more apt for practical use: planned languages that share this characteristic of being explicitly reforms of Volapük will be referred by now as "volapukesque IALs" or "volapukesques" for brevity-with Volapük included as the prototype. Most volapukesques were published in Germany or France between the end of the XIX century and the very beginning of the XX century. Couturat \& Leau (1903) report five direct reforms of Volapük: Hilbe's Zahlensprache, Bauer's Spelin, Fieweger's Dil, Dormoy's Balta, Guardiola's Orba. ${ }^{12}$

Furthermore, among the planned languages reported by the two French mathematicians, there are a couple of other IALs that can be rightly considered volapukesques too. They are von Arnim's Veltparl, published in Opole (Poland) in 1896, and Marchand's Dilpok, published in Besançon (France) in 1898. Even if some influence of Esperanto can be accounted, their model in language planning was still Volapük. Quite interestingly, not every volapukesque IAL reported by Couturat \& Leau (1903) describes correlatives as a system: surprisingly, even the correlatives corresponding to the English who and which are absent in some cases. ${ }^{13}$ For example, the only known correlatives of Orba are den (rendered in French celui-ci 'here') and len (celui-là 'there'). As a side note, correlatives of Dil are not reported because they are very similar to the original ones in Volapük, according to Couturat \& Leau (1903).

\footnotetext{
${ }^{12}$ The review by Couturat \& Leau (1903) is the main reference for interlinguistics, at least for the first half of the XX century.

${ }^{13}$ As the two mathematicians were very precise in their review, it is probable that many language planners did not take correlatives into account, at least as part of the core features of the proposed IAL published at its launch.
} 
Table 7. Circumstantial $W h$-Words in Volapukesques

\begin{tabular}{|l|l|l|l|l|}
\hline \multicolumn{1}{|c|}{ IAL } & Tempus & Causa & Modus & Locus \\
\hline Volapük $^{14}$ & kiüp & kikod & kimiko & kiöp \\
\hline Zahlensprache & qande & kur & kome & dove \\
\hline Spelin & kete & $? ?$ & kefe & keve \\
\hline English & when & why & how & where \\
\hline
\end{tabular}

Table 7 is an elaboration of the data reported in Couturat \& Leau (1903), with English added for control. Spelin substitutes the original $k i$ - prefix with $k e$-, even if the causal circumstantial is not attested. The aim of Bauer, professor of mathematics in high school whose mother tongue was Croatian, was to set up a Sprachwissenschaftiche Kombinatorik (linguistic combinatorics, in Couturat \& Leau 1903: 170). In fact, clear elements of regular derivation-even if definitely a priori-were introduced.

Table 8 (below) shows how "linguistic combinatorics" work in Spelin. The absolute regularity of Spelin let the user to obtain further forms like *petel and *negetel - which are reconstructed by analogy, but not attested, at least in the description by Couturat \& Leau (1903).

Table 8. Correlative Circumstantial System of Spelin

\begin{tabular}{|c|l|l|l|l|}
\hline Type/character & \multicolumn{1}{|c|}{$\begin{array}{c}\text { Locus } \\
(\mathrm{E})\end{array}$} & $\begin{array}{c}\text { Modus } \\
(\mathrm{E})\end{array}$ & $\begin{array}{c}\text { Tempus } \\
(\mathrm{E})\end{array}$ & $\begin{array}{c}\text { Tempus }+ \\
\text { origo (E) }\end{array}$ \\
\hline$?$ & keve & kefe & kete & ketel \\
where & how & when & since when \\
\hline
\end{tabular}

\footnotetext{
${ }^{14}$ I refer to Schleyer's original version of the grammar. The history of Volapük is complex, and its treatment is out of the scope of this paper. However, it seems that correlatives were left untouched in the successive versions of Volapük.
} 


\begin{tabular}{|c|l|l|l|l|}
\hline Type/character & \multicolumn{1}{|c|}{$\begin{array}{c}\text { Locus } \\
(\mathrm{E})\end{array}$} & \multicolumn{1}{|c|}{$\begin{array}{c}\text { Modus } \\
(\mathrm{E})\end{array}$} & $\begin{array}{c}\text { Tempus } \\
(\mathrm{E})\end{array}$ & \multicolumn{1}{c|}{$\begin{array}{c}\text { Tempus }+ \\
\text { origo (E) }\end{array}$} \\
\hline$\rightarrow$ & $\begin{array}{l}\text { eve } \\
\text { there }\end{array}$ & $\begin{array}{l}\text { efe } \\
\text { so }\end{array}$ & $\begin{array}{l}\text { ete } \\
\text { then }\end{array}$ & $\begin{array}{l}\text { etel } \\
\text { since then }\end{array}$ \\
\hline$\forall$ & $\begin{array}{l}\text { peve } \\
\text { everywhere } \\
\text { in every } \\
\text { way }\end{array}$ & $\begin{array}{l}\text { pete } \\
\text { always }\end{array}$ & $\begin{array}{l}\text { *petel } \\
\text { since always? }\end{array}$ \\
\hline$\nsupseteq$ & $\begin{array}{l}\text { negeve } \\
\text { nowhere }\end{array}$ & $\begin{array}{l}\text { negefe } \\
\text { in no way }\end{array}$ & $\begin{array}{l}\text { negete } \\
\text { never }\end{array}$ & $\begin{array}{l}\text { *negetel } \\
\text { since never? }\end{array}$ \\
\hline
\end{tabular}

Analogously, demonstratives are formed per suffix $-f$ (Table 9).

Table 9. Demonstrative Correlatives in Spelin

\begin{tabular}{|l|l|l|l|l|l|l|}
\hline $\begin{array}{l}\text { def } \\
\text { that }\end{array}$ & $\begin{array}{l}\text { gef } \\
\text { that something }\end{array}$ & $\begin{array}{l}\text { negef } \\
\text { nobody }\end{array}$ & $\begin{array}{l}\text { mef } \\
\text { the other }\end{array}$ & $\begin{array}{l}\text { gamef } \\
\text { another }\end{array}$ & $\begin{array}{l}\text { lef } \\
\text { the same }\end{array}$ & $\begin{array}{l}\text { pef } \\
\text { every }\end{array}$ \\
\hline
\end{tabular}

The idea of linguistic combinatorics shows a clear regularity pattern for instance in negatives, e.g., negefe (for locality purposes) and negef (for deictic purposes). However, this preference to regularity has the drawback of having too similar forms, e.g., pef ('every') and pefe ('in every way'). Interestingly, a comparison to the system individuated by Frank \& Lobin (1997) presented in Table 3 shows that apparently there is no indefinite correlatives in Spelin (symbol: $\exists$ ).

Not every volapukesque grants so much privilege to regularity over similarity. In fact, unlike Spelin, Hilbe's Zahlensprache shows a clear influence by Latin.

Table 10. The Correlative System in Zahlensprache

\begin{tabular}{|c|l|l|l|l|}
\hline Type/character & $\begin{array}{c}\text { Persona } \\
(\mathrm{A})\end{array}$ & $\begin{array}{c}\text { Persona } \\
(\mathrm{A})\end{array}$ & \multicolumn{1}{|c|}{$\begin{array}{c}\text { Modus } \\
(\mathrm{E})\end{array}$} & $\begin{array}{c}\text { Temporal + } \\
\text { goal (E) }\end{array}$ \\
\hline $\begin{array}{c}\text { Interrogative } \\
(?)\end{array}$ & $\begin{array}{l}\text { li ki? } \\
\text { who? }\end{array}$ & $\begin{array}{l}\text { li qale? } \\
\text { which? }\end{array}$ & $\begin{array}{l}\text { li kome? } \\
\text { how? }\end{array}$ & $\begin{array}{l}\text { bis qande? } \\
\text { until when? }\end{array}$ \\
\hline
\end{tabular}




\begin{tabular}{|c|l|l|l|l|}
\hline $\begin{array}{c}\text { Demonstrative } \\
(\rightarrow)\end{array}$ & $\begin{array}{l}\text { soki } \\
\text { that }\end{array}$ & $\begin{array}{l}\text { soqale } \\
\text { that }\end{array}$ & $\begin{array}{l}\text { sokome } \\
\text { in that way }\end{array}$ & $\begin{array}{l}\text { soki } \\
\text { that }\end{array}$ \\
\hline
\end{tabular}

Table 10 shows that Hilbe, himself fascinated by the regularity of mathematics, conceived Zahlensprache (number language) in order "to obtain a science of linguistic calculus" (Couturat \& Leau 1903: 97). All interrogative clauses are always introduced by $l i-$ Zahlensprache extending the original use of Volapük, where $l i$ introduces only yes/no questions. Moreover, there are analytical forms to fill special needs, like bis qande. Nonetheless, Hilbe considered similarity too as a valid principle, in particular similarity with Latin, which was not unusual for that time (1901).

As a provisional conclusion, volapukesques show very different strategies about correlatives: from absolute regularity in the case of Spelin, to considerable similarity to Latin in Zahlensprache.

\section{Correlatives in Esperanto and its Daughters}

Although certain morphosyntactic traits of Esperanto are clearly non-SAE (Pennacchietti 1987), it is still part of the SAE sprachbund. In particular, some traits of Esperanto are typically Slavic (Comrie 1996), while most if not all reforms of Esperantowhich are called since Bausani (1974) "esperantidos"—cut off most influences from Slavic languages in particular, but also Germanic ones, with the important exception of English (Gobbo 2005b). In particular, one of the most criticized parts of the Esperanto grammars has always been the correlative system, because it is regular but not similar to any widely used natural language. However, Esperanto correlatives show a considerable degree of similarity with Lithuanian ones (see Table 11 below), Lithuanian 
being part of Zamenhof's repertoire (Künzli 2010). ${ }^{15}$

In particular, the interrogative (?) and demonstrative $(\rightarrow)$ prefixes are the same in Esperanto and Lithuanian: respectively, $k$ - and $t$-. Moreover, Lithuanian shows a indefinite $(\exists$ ) prefix $k a z ̌-$ while Esperanto shows a zero morpheme prefix, and the universal $(\forall)$ Lithuanian prefix vis- is rendered in Esperanto through $\hat{c}^{-}$. The negative correlative system in Lithuanian is not as regular as the Esperanto one, but a relation between the Lithuanian nie- and the Esperanto nen- is evident.

However, even if Esperanto correlatives can be rightly related to Lithuanian for regularity, and are similar in some respects, they are hardly similar to any other natural language. In fact, they are usually considered as an a priori part of the Esperanto grammar, like for example Spelin (Table 8) - and often attacked as "volapukisms" by the supporters of other IALs.

Finally, the corpus-based analysis of the Esperanto grammar by Gledhill (2000) has shown that some forms are very frequent while others are very rare: in particular, cial (for every reason) and ciom (every quantity) are never found. This fact can be used as an argument against the opportunity of such a wide system of the correlatives (in Table 11).

Esperantidos show major changes in respect of the correlative system. There are two variables in such changes that should be taken into account. In fact, some esperantidos retain the wideness of the Esperanto correlative system - the prefixes as indicated by Frank \& Lobin (1997) and the meaning of the suffixes along the grammar characters indicated in Table 11 -while others show a reduced system (Libert 2008: 91).

\footnotetext{
${ }^{15}$ Table 11 is an elaboration of Gledhill (2000: 83) where English translation were added from Wells (2010: XIII). Gledhill emphasizes the influence of Lithuanian over Esperanto correlative, but Lithuanian influences other small but significative parts of the Esperanto lexicon; for example, Esperanto borrows the adverbial pseudofinal -aŭ from Lithuanian (Poška 1981).
} 
Table 11. Correlatives in Esperanto, Lithuanian, and English

\begin{tabular}{|c|c|c|c|c|c|}
\hline & $?$ & $\rightarrow$ & $\exists$ & $\forall$ & $\nexists$ \\
\hline $\begin{array}{l}\text { Factum } \\
\text { (O) }\end{array}$ & $\begin{array}{l}\text { kio kas } \\
\text { what }\end{array}$ & $\begin{array}{l}\text { tio tai } \\
\text { that }\end{array}$ & $\begin{array}{l}\text { io } \boldsymbol{k a z ̌ k a s} \\
\text { something }\end{array}$ & $\begin{array}{l}\text { cio viskas } \\
\text { everything }\end{array}$ & $\begin{array}{l}\text { nenio } \\
\text { niekas } \\
\text { nothing }\end{array}$ \\
\hline $\begin{array}{l}\text { Quantum } \\
\text { (O) }\end{array}$ & $\begin{array}{l}\text { kiom } \text { kiek } \\
\text { how much }\end{array}$ & $\begin{array}{l}\text { tiom } \\
\text { tiek } \\
\text { so much }\end{array}$ & $\begin{array}{l}\text { iom } \\
\text { kažkiek } \\
\text { somewhat }\end{array}$ & $\begin{array}{l}\text { ĉiom bet } \\
\text { kiek every } \\
\text { quantity }\end{array}$ & $\begin{array}{l}\text { neniom } \\
\text { ne kiek } \\
\text { none }\end{array}$ \\
\hline $\begin{array}{l}\text { Persona } \\
\text { (A) }\end{array}$ & $\begin{array}{l}\text { kiu } k \text { uris } \\
\text { which, who }\end{array}$ & $\begin{array}{l}\text { tiu } \\
\text { tas } \\
\text { that one }\end{array}$ & $\begin{array}{l}\text { iu } \\
\text { kažkuris } \\
\text { someone }\end{array}$ & $\begin{array}{l}\text { ĉiu } \\
\text { kiekvienas } \\
\text { everyone }\end{array}$ & $\begin{array}{l}\text { neniu } \\
\text { niekas } \\
\text { no one, no }\end{array}$ \\
\hline $\begin{array}{l}\text { Qualitas } \\
\text { (A) }\end{array}$ & $\begin{array}{l}\text { kia } \text { koks } \\
\text { what kind } \\
\text { of }\end{array}$ & $\begin{array}{l}\text { tia } \\
\text { toks that } \\
\text { kind of }\end{array}$ & $\begin{array}{l}\text { ia } \boldsymbol{k a z ̌ k o k s} \\
\text { some kind } \\
\text { of }\end{array}$ & $\begin{array}{l}\text { cia visoks } \\
\text { every kind } \\
\text { of }\end{array}$ & $\begin{array}{l}\text { nenia } \\
\text { joks } \\
\text { no kind of }\end{array}$ \\
\hline $\begin{array}{l}\text { Genitivus } \\
\text { (A) }\end{array}$ & $\begin{array}{l}\text { kies } \\
\text { kieno } \\
\text { whose }\end{array}$ & $\begin{array}{l}\text { ties } \\
\text { to, tos } \\
\text { that one's }\end{array}$ & $\begin{array}{l}\text { ies } \\
\text { kažkieno } \\
\text { someone's }\end{array}$ & $\begin{array}{l}\text { ĉies } \\
\text { vis } u_{t} \\
\text { everyone's }\end{array}$ & $\begin{array}{l}\text { nenies } \\
\text { niekieno } \\
\text { no one's }\end{array}$ \\
\hline $\begin{array}{l}\text { Tempus } \\
\text { (E) }\end{array}$ & $\begin{array}{l}\text { kiam } \\
\text { kada } \\
\text { when }\end{array}$ & $\begin{array}{l}\text { tiam } \\
\text { tada } \\
\text { then }\end{array}$ & $\begin{array}{l}\text { iam } \\
\text { kažkada } \\
\text { sometime }\end{array}$ & $\begin{array}{l}\text { ĉiam } \\
\text { visada } \\
\text { always }\end{array}$ & $\begin{array}{l}\text { neniam } \\
\text { niekada } \\
\text { never }\end{array}$ \\
\hline $\begin{array}{l}\text { Causa } \\
\text { (E) }\end{array}$ & $\begin{array}{l}\text { kial } \\
\text { kodel } \\
\text { why }\end{array}$ & $\begin{array}{l}\text { tial } \\
\text { todel } \\
\text { therefore }\end{array}$ & $\begin{array}{l}\text { ial } \\
\boldsymbol{k a z ̌ k o d e ̀ l} \\
\text { for some } \\
\text { reason }\end{array}$ & $\begin{array}{l}\text { cial dèl vis- } \\
\text { okiu prie- } \\
\text { žasčiu } \\
\text { for every } \\
\text { reason }\end{array}$ & $\begin{array}{l}\text { nenial be } \\
\text { jokios prie- } \\
\text { žasties } \\
\text { for no } \\
\text { reason }\end{array}$ \\
\hline $\begin{array}{l}\text { Modus } \\
\text { (E) }\end{array}$ & $\begin{array}{l}\text { kiel } \\
\text { kaip } \\
\text { how }\end{array}$ & $\begin{array}{l}\text { tiel taip } \\
\text { so, in that } \\
\text { way }\end{array}$ & $\begin{array}{l}\text { iel } \\
\text { kažkaip } \\
\text { somehow }\end{array}$ & $\begin{array}{l}\text { ĉiel visaip } \\
\text { in every } \\
\text { way }\end{array}$ & $\begin{array}{l}\text { neniel } \\
\text { niekaip } \\
\text { in no way }\end{array}$ \\
\hline $\begin{array}{l}\text { Locus } \\
\text { (E) }\end{array}$ & $\begin{array}{l}\text { kie } \\
\text { kur } \\
\text { where }\end{array}$ & $\begin{array}{l}\text { tie } \\
\text { ten } \\
\text { there }\end{array}$ & $\begin{array}{l}\text { ie } \\
\text { kažkur } \\
\text { somewhere }\end{array}$ & $\begin{array}{l}\text { cie } \\
\text { visur } \\
\text { everywhere }\end{array}$ & $\begin{array}{l}\text { nenie } \\
\text { niekur } \\
\text { nowhere }\end{array}$ \\
\hline
\end{tabular}

The first esperantido was a reform proposed by Zamenhof himself to the readers of the first journal written in Esperanto, $L a$ Esperantisto. The reform was rejected by the readers themselves after a referendum in 1894 (Haupenthal 1988). 
Table 12. Temporal Correlatives in Esperanto and Esperanto (1894)

\begin{tabular}{|l|l|l|l|l|}
\hline \multicolumn{1}{|c|}{$?$} & \multicolumn{1}{c|}{$\rightarrow$} & \multicolumn{1}{c|}{$\exists$} & \multicolumn{1}{c|}{$\forall$} & \multicolumn{1}{c|}{$\exists$} \\
\hline $\begin{array}{l}\text { kiam } \\
\text { kvandu }\end{array}$ & $\begin{array}{l}\text { tiam } \\
\text { tum }\end{array}$ & $\begin{array}{l}\text { iam } \\
\text { alikvam }\end{array}$ & $\begin{array}{l}\text { ciam } \\
\text { semper }\end{array}$ & $\begin{array}{l}\text { neniam } \\
\text { nunkvam }\end{array}$ \\
\hline
\end{tabular}

Esperanto (1894) retains all the wideness of the Esperanto correlative system, but it sacrifices regularity in favor of similarity with Latin, as shown in Table 11. Although Esperanto (1894) did not influence the history of Esperanto directly, it was taken as a start point for the construction of the following esperantidos, in particular Ido. $^{16}$

Table 13 (below) shows that Ido retains part of the regularity of Esperanto, although its morphemes are fairly more similar to Latin and therefore more familiar to most learners in 1908, when Ido was published: in particular, the Esperanto $\hat{c}$ - is turned into omn-, while nen- becomes nul-. However, it is not intuitive why the Latin prefix $q u$ - is retained in some forms (e.g., Ido and Latin quo, English what) but not in others-for instance, the Latin quando becomes in Ido kande. Furthermore, the authoritative grammar of Ido by de Beaufront - recently (2005) republished in digital form-uses the word "correlatives" only once: the author programmatically rejects to consider these words as a regular system, in order to take a distance from Esperanto.

Table 13. Some Correlatives in Esperanto and Ido in Comparison

\begin{tabular}{|c|l|l|l|l|l|}
\hline & \multicolumn{1}{|c|}{ ? } & \multicolumn{1}{c|}{$\rightarrow$} & \multicolumn{1}{c|}{$\exists$} & \multicolumn{1}{c|}{$\forall$} & \multicolumn{1}{c|}{$\sharp$} \\
\hline $\begin{array}{c}\text { Factum } \\
(\mathrm{O})\end{array}$ & $\begin{array}{l}\text { kio } \\
\text { quo }\end{array}$ & $\begin{array}{l}\text { tio } \\
\text { to, } \text { ito }\end{array}$ & $\begin{array}{l}\text { io } \\
\text { ulo }\end{array}$ & $\begin{array}{l}\text { ciio } \\
\text { omno }\end{array}$ & $\begin{array}{l}\text { nenio } \\
\text { nulo }\end{array}$ \\
\hline
\end{tabular}

\footnotetext{
${ }^{16}$ In the early XX century, a common argument of Idists in defence of the necessity of a reform of Esperanto, was the fact that the first reform of Esperanto was proposed by Zamenhof himself (Large 1985).
} 


\begin{tabular}{|c|c|c|c|c|c|}
\hline & $?$ & $\rightarrow$ & $\exists$ & $\forall$ & $\nexists$ \\
\hline $\begin{array}{l}\text { Persona } \\
\text { (A) }\end{array}$ & $\begin{array}{l}\text { kiu } \\
\text { qui, qua }\end{array}$ & tiu & $\begin{array}{l}\text { iu } \\
\boldsymbol{u l} a, \boldsymbol{u l} i\end{array}$ & $\begin{array}{l}\text { ciu } \\
\text { omnu, omni }\end{array}$ & $\begin{array}{l}\text { neniu } \\
\text { nulu, nuli }\end{array}$ \\
\hline $\begin{array}{l}\text { Tempus } \\
\text { (E) }\end{array}$ & $\begin{array}{l}\text { kiam } \\
\text { kande }\end{array}$ & $\begin{array}{l}\text { tiam } \\
\text { lore }\end{array}$ & $\begin{array}{l}\text { iam } \\
\text { ultempe }\end{array}$ & $\begin{array}{l}\text { ciam } \\
\text { omnatempe, } \\
\text { sempre }\end{array}$ & $\begin{array}{l}\text { neniam } \\
\text { nultempe }\end{array}$ \\
\hline $\begin{array}{l}\text { Locus } \\
\text { (E) }\end{array}$ & $\begin{array}{l}\text { kie } \\
\text { ube }\end{array}$ & $\begin{array}{l}\text { tie } \\
\text { ibe }\end{array}$ & $\begin{array}{l}\text { ie } \\
\text { ulube }\end{array}$ & $\begin{array}{l}\text { cie } \\
\text { omnube }\end{array}$ & $\begin{array}{l}\text { nenie } \\
\text { nulube }\end{array}$ \\
\hline
\end{tabular}

This awkwardness in presenting correlatives as a system in a new IAL project after Esperanto is not a prerogative of Ido only. In fact, only Jespersen's Novial (1928) tries to propose an Einbau language (Gobbo 2008), i.e., an explicit try to merge a "new IAL"- this is the meaning of the name "nov-IAL'-putting together the "best" features of previous planned languages, in particular Esperanto, Ido, Latino sine Flexione and Occidental, which are explicitly referred in the introduction (Jespersen 2006).

Table 14. Some Correlatives in Ido and Novial in Comparison

\begin{tabular}{|c|c|c|c|c|c|}
\hline & $?$ & $\rightarrow$ & $\exists$ & $\forall$ & $\nexists$ \\
\hline $\begin{array}{l}\text { Tempus } \\
\text { (E) }\end{array}$ & $\begin{array}{l}\text { kande } \\
\text { quitem }\end{array}$ & $\begin{array}{l}\text { lore } \\
\text { titem }\end{array}$ & $\begin{array}{l}\text { ultempe } \\
\text { irgitem }\end{array}$ & $\begin{array}{l}\text { omnatempe } \\
\text { omnitem }\end{array}$ & $\begin{array}{l}\text { nultempe } \\
\text { nulitem }\end{array}$ \\
\hline $\begin{array}{l}\text { Locus } \\
\text { (E) }\end{array}$ & $\begin{array}{l}\text { ube } \\
\text { quilok, vor }\end{array}$ & $\begin{array}{l}\text { ibe } \\
\text { tilok, dar }\end{array}$ & $\begin{array}{l}\text { ulube } \\
\text { irgilok }\end{array}$ & $\begin{array}{l}\text { omnube } \\
\text { omnilok }\end{array}$ & $\begin{array}{l}\text { nulube } \\
\text { nulilok }\end{array}$ \\
\hline
\end{tabular}

The paradigm of circumstantial correlatives (which in Novial are: time, place, degree, manner) is perfectly regular-more like Esperanto than Ido - while morphemes are quite similar to Latin: e.g., Novial -tem stands for Latin tempus (Table 14). However, although the regularity behind correlatives suggest a clear system, Jespersen presents adverbs, prepositions, and conjunctions under the 
comprehensive term 'particles,' where correlatives can also be found, but without special emphasis. In particular, unlike the other IALs seen here, in Novial the interrogative and relative correlatives are distinguished: for instance, quand is the interrogative (when?) while kand is the relative (when...). The reason behind this nuanceclarified by Jespersen himself - is found in German and French: in German, the interrogative temporal word is wann while the relative correspondent is wenn, and in French the relative form is sometimes signed by lorsque instead of quand, even if this last form can be used in both constructions either.

The last esperantido which retains explicitly regularity as a key feature for correlatives is Alfandari's Neo, originally published in 1961.

Table 15. Some Correlatives in Neo, French, and English

\begin{tabular}{|c|c|c|c|c|c|}
\hline & $\rightarrow$ & $\exists$ & $\forall$ & $\nexists$ & Otherness \\
\hline $\begin{array}{l}\text { Factum } \\
\text { (O) }\end{array}$ & $\begin{array}{l}\text { shako } \\
\text { chaque } \\
\text { chose } \\
\text { that }\end{array}$ & $\begin{array}{l}\text { somun } \\
\text { quelque } \\
\text { chose } \\
\text { something }\end{array}$ & $\begin{array}{l}\text { toto } \\
\text { tout } \\
\text { everything }\end{array}$ & $\begin{array}{l}\text { nilo } \\
\text { rien } \\
\text { nothing }\end{array}$ & $\begin{array}{l}\text { somoso } \\
\text { quelque } \\
\text { chose } \\
\text { d'autre }\end{array}$ \\
\hline $\begin{array}{c}\text { Persona } \\
\text { (A) }\end{array}$ & $\begin{array}{l}\text { shakun } \\
\text { chacun } \\
\text { that one }\end{array}$ & $\begin{array}{l}\text { somun } \\
\text { quelqu'un } \\
\text { someone }\end{array}$ & $\begin{array}{l}\text { totun } \\
\text { chacun } \\
\text { everyone }\end{array}$ & $\begin{array}{l}\text { nilun } \\
\text { aucun } \\
\text { no one }\end{array}$ & $\begin{array}{l}\text { somosun } \\
\text { quelqu'un } \\
\text { d'autre }\end{array}$ \\
\hline $\begin{array}{l}\text { Modus } \\
\text { (E) }\end{array}$ & $\begin{array}{l}\text { shake } \\
\text { de chaque } \\
\text { façon } \\
\text { so }\end{array}$ & $\begin{array}{l}\text { some } \\
\text { de quelque } \\
\text { façon } \\
\text { somehow }\end{array}$ & $\begin{array}{l}\text { tote } \\
\text { de toutes } \\
\text { façons } \\
\text { in every way }\end{array}$ & $\begin{array}{l}\text { nile } \\
\text { nullement } \\
\text { in no way }\end{array}$ & $\begin{array}{l}\text { somose } \\
\text { de quelque } \\
\text { autre façon }\end{array}$ \\
\hline
\end{tabular}

Table 15 reports some correlatives in Neo. This IAL was presented by Alfandari in French, and Table 15 reports it, following the elaboration by Libert (2008: 95), with the addition of English. Neo expands the wideness of the original Esperanto system with the category "otherness," but at the expense of interrogatives (symbol: 
?), which are unbelievably absent. Moreover, unlike the other IALs, the main source languages of Neo are French and English, not Latin. In fact, most forms are heavily influenced by French: for instance, chaque becomes in Neo shak-, written through an English-like ortography, while the Neo som- is borrowed directly from the English some.

A final remark about the evolution of Esperanto should be put now. As well as Ido and Novial, which propose two forms in parallel in some cases (e.g., Ido omnatempe and sempre, Novial quilok and vor), in Esperanto a parallel form of kiel (how) emerged with a very similar use, i.e., kiamaniere, in what way (Gledhill 2000: 88). Moreover, the need of a correlative category "otherness" shown in Neo can be encountered in the irregular form aliel (in another way), which is often deprecated (for example in Wells 2010: XXIII) but firmly attested, even if there is already the more transparent form alimaniere. ${ }^{17}$ These facts suggest that certain proposed forms of IALs different from Esperanto had a direct or indirect backward effect on Esperanto too, witnessing the need or at least the opportunity of their existence.

\section{Correlatives in Romance IALs}

There is a turning point from esperantidos, after the failure of Novial, which was used by less than ten people, Jespersen included (Gobbo 2009): occidentalization (Gobbo 2005b). In fact, most IALs planned afterwards resemble a regularized version of Romance languages, particularly French and Italian, with some inserts of English. For this reason, this family of planned languages can be

\footnotetext{
${ }^{17}$ In the largest Esperanto corpus available, Tekstaro <www.tekstaro.com>, there are 29 entries of aliel (2011 July) in the whole corpus, while in Zamenhof's use aliel is completely absent. Another irregular form quite used is alies (other's), even if the correspondent regular form aliula is possible.
} 
collectively called "Romance IALs," even if this name is sometimes hardly contested by their adherents - for instance, de Wahl (1929).

The most important Romance IAL of the first half of the XX century is Occidental. Launched in 1922, Occidental had some success in the 1930s. Its name was changed in Interlingue after 1949, soon after de Wahl's death, without substantial difference in structure, and since then it is known with this name. Its grammar was published through the official review Cosmoglotta. A lot of effort was spent to regularize the derivation of romance or Latin words from thematic roots and their derivational affixes, while far less attention was paid to correlatives. Correlatives were published as a table only in a small leaflet by Berger (1949), while in the more authoritative grammar by Haas (1956) they receive no special treatment.

Table 16 (below) reports the presentation of correlatives made by Berger (1949) with the addition of French, in order to show how some forms are very similar or identical. In particular, tant, quande, $u$, partú are clearly borrowings from French. A notable exception is sempre (always), which is identical to Italian. However, Occidental tries to retain regularity as well: all temporal correlatives end in -de, except for sempre (but why not *tutquande?), while all indefinites start in al-.

Table 16. Some Correlatives in Occidental and in French

\begin{tabular}{|c|c|c|c|c|c|}
\hline & $?$ & $\rightarrow$ & $\exists$ & $\forall$ & $\nexists$ \\
\hline $\begin{array}{l}\text { Quantum } \\
\text { (O) }\end{array}$ & $\begin{array}{l}\text { quant } \\
\text { combien }\end{array}$ & $\begin{array}{l}\operatorname{tant} \\
\operatorname{tant}\end{array}$ & $\begin{array}{l}\text { alquant } \\
\text { un peu }\end{array}$ & $\begin{array}{l}\text { tut-men } \\
\text { tout }\end{array}$ & $\begin{array}{l}\text { nequant } \\
\text { rien }\end{array}$ \\
\hline $\begin{array}{l}\text { Modus } \\
\text { (E) }\end{array}$ & $\begin{array}{l}\text { qualmen } \\
\text { comment }\end{array}$ & $\begin{array}{l}\text { talmen } \\
\text { de telle } \\
\text { maniere }\end{array}$ & $\begin{array}{l}\text { in alcun } \\
\text { maniere } \\
\text { d'un certaine } \\
\text { manière }\end{array}$ & $\begin{array}{l}\text { in omni } \\
\text { maniere } \\
\text { de toutes les } \\
\text { manière }\end{array}$ & $\begin{array}{l}\text { nequalmen } \\
\text { d'aucune } \\
\text { manière }\end{array}$ \\
\hline $\begin{array}{l}\text { Tempus } \\
\text { (E) }\end{array}$ & $\begin{array}{l}\text { quande } \\
\text { quand }\end{array}$ & $\begin{array}{l}\text { tande } \\
\text { alors }\end{array}$ & $\begin{array}{l}\text { alquande } \\
\grave{a} \text { un } \\
\text { certain moment }\end{array}$ & $\begin{array}{l}\text { sempre } \\
\text { toujours }\end{array}$ & $\begin{array}{l}\text { nequande } \\
\text { jamais }\end{array}$ \\
\hline
\end{tabular}




\begin{tabular}{|c|l|l|l|l|l|}
\hline $\begin{array}{c}\text { Locus } \\
(\mathrm{E})\end{array}$ & $\begin{array}{l}\mathrm{u} \\
\text { où }\end{array}$ & $\begin{array}{l}\text { ta } \\
\text { là }\end{array}$ & $\begin{array}{l}\text { alcú } \\
\text { quelque part }\end{array}$ & $\begin{array}{l}\text { partú } \\
\text { partout }\end{array}$ & $\begin{array}{l}\text { necú } \\
\text { nulle part }\end{array}$ \\
\hline
\end{tabular}

Unlike Occidental, Interlingua, the IAL sponsored by IALA and planned by Alexander Gode with Hugh Blair (1951) is more adherent to the Latin prototype, but with strong influences from English, in respect of meaning - it is worth noticing that in its last period IALA was settled in New York. In particular, regularity is less important than similarity in the correlative system. In fact, correlatives are treated apart neither in the grammar by Gode \& Blair (1951) nor in the Interlingua-English Dictionary by Gode (1951).

Table 17 shows the same correlatives of Table 16, in order to facilitate a comparison between Occidental-Interlingue and Interlingua. In fact, the Occidental prefix al-corresponds to the Interlingua prefix ali-, as well as the prefix $q u$-. However, in some parts Interlingua is more regular than Occidental (e.g., the universal series with omne) while in others not (e.g., the temporal series).

Table 17. Some Correlatives in Interlingua and in English

\begin{tabular}{|c|l|l|l|l|l|}
\hline & \multicolumn{1}{|c|}{$?$} & \multicolumn{1}{|c|}{$\rightarrow$} & \multicolumn{1}{|c|}{$\exists$} & \multicolumn{1}{|c|}{$\sharp$} \\
\hline Quantum (O) & $\begin{array}{l}\text { quanto } \\
\text { how much }\end{array}$ & $\begin{array}{l}\text { tanto } \\
\text { so much }\end{array}$ & $\begin{array}{l}\text { aliquanto } \\
\text { somewhat }\end{array}$ & $\begin{array}{l}\text { omne quanto } \\
\text { every quantity }\end{array}$ & $\begin{array}{l}\text { nulle } \\
\text { none }\end{array}$ \\
\hline Modus (E) & $\begin{array}{l}\text { como } \\
\text { how }\end{array}$ & $\begin{array}{l}\text { ita } \\
\text { so }\end{array}$ & $\begin{array}{l}\text { de alicun } \\
\text { maniera } \\
\text { somehow }\end{array}$ & $\begin{array}{l}\text { in omne } \\
\text { maniera } \\
\text { in every way }\end{array}$ & $\begin{array}{l}\text { nullemente } \\
\text { in no way }\end{array}$ \\
\hline Lempus (E) & $\begin{array}{l}\text { quando } \\
\text { when }\end{array}$ & $\begin{array}{l}\text { tunc, alora } \\
\text { then }\end{array}$ & $\begin{array}{l}\text { aliquando } \\
\text { sometime }\end{array}$ & $\begin{array}{l}\text { semper } \\
\text { always }\end{array}$ & $\begin{array}{l}\text { nunquam } \\
\text { never }\end{array}$ \\
\hline where & $\begin{array}{l}\text { ibi } \\
\text { there }\end{array}$ & $\begin{array}{l}\text { aliubi } \\
\text { somewhere }\end{array}$ & $\begin{array}{l}\text { in omnes } \\
\text { partes } \\
\text { everywhere }\end{array}$ & $\begin{array}{l}\text { nusquam, } \\
\text { in nulle } \\
\text { parte } \\
\text { nowhere }\end{array}$ \\
\hline
\end{tabular}


Romance IALs claim to be "immediate readable" by people educated in a European Kultursprache, a culture language-in particular English, French or Latin - and for this reason the regular structure of correlatives gets opaque compared to IALs more inclined to regularity, such as Esperanto or Novial.

\section{Correlatives in Fictional Languages: The Cases of Klingon and Na'vi}

As described in section 1, there are three dimensions of analysis of planned languages: publicity, purpose (e.g., auxiliary, religious, fictional) and the diamesic axis (i.e., the main channel of use, whether written or spoken).

While non-auxiliary languages, and in particular religious languages, are often esoteric (Bausani 1974), more recent fictional languages - such as Klingon or $\mathrm{Na}$ 'vi-are public (although publicity does not imply being in the public domain) in order to let fans use them for the creation of the so-called "expanded universe."

Interestingly, no Tolkien's language apparently shows any correlative. Kloczko $(2002,2004)$ has extracted a corpus-based grammar of every language planned by Tolkien, complete with the appropriate dictionaries. Unfortunately, most texts are poems, where correlatives seem to be never used. After all, the aim of Tolkien was not an actual use by other people, but rather they served as part of the background of Middle-Earth, its fictional world described in his novels and essays, which is firmly grounded in Old and Middle English language and literature (Solopova 2009).

On the contrary, there is a precise and authoritative description of Klingon and Na'vi grammar. Therefore, they were chosen in this paper in order to control if the auxiliary purpose influence the degree of regularity in correlatives.

It is worth noticing that both languages were commissioned to 
professionals who planned them so that they appear of "alien" origin, in particular to English speakers: henceforth, any SAE trait was carefully avoided. In other words, the criterion of similarity was still applied, but in negative: instead of being similar, they should appear different. For this reason, phonology and the lexicon appear unfamiliar to learners untrained in linguistic typology.

On the other kind, Klingon and Na'vi are learned for pleasure, so they should avoid unnecessary irregularities: in other words, regularity is also observed in the language planning phase.

In particular, Klingon shows considerable elasticity in forming relative clauses, according to the typological taxonomy proposed by Comrie (1989: 155).

(6) a. qIp-pu' hit-PERF. ${ }^{18}$ 'the officer who hit him/her'

b. yaS officer 'the officer whom he/she hit'

c. qIp-pu' hit-PERF.

$$
\text { -bogh }
$$

who/which

qIp-pu'

hit-PERF.

\section{-bogh}

who/which
yaS

officer

-bogh

who/which

vI-legh

I him/her-see

vI-legh

I him/her-see

d. yaS

qIp-pu'

-bogh

who/which

'I see the officer whom he/she hit.'

(7) a. yaS officer 'who sees the officer?'
b. 'Iv
$-\operatorname{legh}$
yaS
who?
see

\footnotetext{
18 PERF. is used as an abbreviation for perfective.
} 
'Whom does the officer see?'

Examples (6) and (7), elaborated from Okrand (1992: 63-64, 69), show how interrogative and relative clauses work in Klingon, which is a OVS language and coherently presents postpositions, which are quite unfamiliar for English speakers (negative similarity).

In Klingon, there are 5 types of nominal suffixes and 9 types of verbal suffixes. The series of correlatives is classified under the type 9 verbal suffixes. While there is one non-interrogative, relative correlative marker, -bogh, the interrogative correlatives function in the way exemplified in (7).

Table 18. Interrogative Correlatives in Klingon

\begin{tabular}{|c|c|c|c|c|c|c|}
\hline 'Iv & nuq & chay' & ghorgh & nuqDaq & qatlh & 'ar \\
\hline $\begin{array}{c}\text { who? } \\
(\mathrm{O})\end{array}$ & $\begin{array}{c}\text { what? } \\
(\mathrm{O})\end{array}$ & $\begin{array}{c}\text { how? } \\
(\mathrm{E})\end{array}$ & $\begin{array}{c}\text { when? } \\
(\mathrm{E})\end{array}$ & $\begin{array}{c}\text { where? } \\
(\mathrm{E})\end{array}$ & $\begin{array}{c}\text { why? } \\
(\mathrm{E})\end{array}$ & $\begin{array}{c}\text { how much? } \\
(\mathrm{E})\end{array}$ \\
\hline
\end{tabular}

Table 18 shows that interrogative correlatives in Klingon are irregular, except for nuqDaq, which is composed by nuq ('what') and the type 5 nominal suffix -Daq, which is a proximal locative: "This suffix indicates that something is happening (or has happened or will happen) in the vicinity of the noun to which it is attached" (Okrand 1992: 27). Demonstratives are expressed through nouns in Klingon, and they are irregular indeed: for example, naDev corresponds to 'here,' $p a$ ' to 'there,' Dat to 'everywhere.'

In sum, the strategy behind the language planning of Klingon is regularity in syntax, while morphology is highly idiosyncratic, perhaps to increase the appearance of "exoticism" in the Klingon language.

Unlike Klingon, the syntax of Na'vi is rich and complex. For example, there are six cases: subjective, agentive, patientive, dative, genitive, and topical - it is worth noticing that $\mathrm{Na}$ 'vi is pragmatically 
split-ergative too. Na'vi is the language spoken by the blue people of Pandora, a key part of James Cameron's Avatar universe. Since the success of the blockbuster movie - published in 2009-a lot of resources freely available in the web were provided, so that quite quickly a community of enthusiasts took formed around the web site dedicated to the language. ${ }^{19}$ However, the grammar was not definite in every detail by the language planner, who presented only a sketch of it in a blog specialized in linguistics (Frommer 2009). This fact instigate enthusiasts to extract the grammar from the corpus, as Kloczko $(2002,2004)$ already made from Tolkien's languages, with the crucial difference that Tolkien was dead during this process, while Frommer is well alive, although he seems not very involved in these efforts, nor in the community.

There are two main sources for Na'vi by now (2011 July). First, the reference grammar written in English by Annis (2011), which is constantly updated in its details; second, the Na'vi-English official dictionary, which is even more quickly updated, being in constant expansion (Miller \& Scheideman 2011). In any case, correlatives, being part of the core of the language, are well defined.

In Na'vi, there is the attributive (Tesneèrian symbol: A) particle $a$ which is used to transform the whole sentence in a adjunctive, so that relatives follow the same rules of adjectives. This particle is very used in Na'vi, sometimes as a preposition, sometimes as a postposition. For instance, the English expression the man on the moon is rendered literally as "the on-moon-attribute man." Moreover, there is a "resumptive pronoun" for animate heads ( $p o$ ) and one for inanimate (tsaw) when the head of the relative clause is neither the subject nor the direct object (Annis 2011: 46).

If it is true that syntax is very complex, on the other kind morphology shows a considerable degree of regularity. In particular, correlatives are called explicitly as such, and presented in a table

\footnotetext{
${ }^{19}$ The permanent link of the web site is <www.learnnavi.org $>$.
} 
along with their English counterparts, although without interrogatives (Annis 2011: 14). That table was elaborated in Table 19 (see below), where some part were added from the more recent dictionary. With the notable exception of $k e^{\prime} u$ ('nothing'), the correlative system of $\mathrm{Na}$ 'vi is perfectly regular, in a way similar to Zahlensprache, Esperanto or Neo, which were analyzed previously. It is worth noticing that some forms are still missing, while the universal locative correlative answer kawtseng $^{P}$ is a proposal by Annis. Perhaps *frafya ('in every way') and *kawfya ('in no way') would be added in the future, thanks to regularity.

Finally, morphology is highly productive in Na'vi. For example, from the lexeme krr ('time') Na'vi users can produce not only the correlatives shown in Table 19 but other regular forms as well, such as tsakrrvay ('until then'; vay is 'up to'), fitrr ('today,' lit. 'current time'), trram ('yesterday,' lit. 'previous time'), and trray ('tomorrow,' lit. 'next time'), all found in Miller \& Scheideman (2011) — trr being an allomorph of krr for phonotactic reasons.

Table 19. Correlatives in Na'vi with Translation in English

\begin{tabular}{|c|l|l|l|l|l|}
\hline \multicolumn{1}{|c|}{$?$} & \multicolumn{1}{|c|}{$\rightarrow$} & \multicolumn{1}{|c|}{$\exists$} & \multicolumn{1}{|c|}{$\sharp$} \\
\hline $\begin{array}{c}\text { Persona } \\
(\mathrm{A})\end{array}$ & $\begin{array}{l}\text { pesu, tupe } \\
\text { who }\end{array}$ & $\begin{array}{l}\text { tsatu } \\
\text { that } \text { one }\end{array}$ & $\begin{array}{l}\text { tuteo } \\
\text { someone }\end{array}$ & $\begin{array}{l}\text { frapo } \\
\text { everyone }\end{array}$ & $\begin{array}{l}\text { kawtu } \\
\text { none }\end{array}$ \\
\hline $\begin{array}{c}\text { Factum } \\
(\mathrm{O})\end{array}$ & $\begin{array}{l}\text { peu, 'upe } \\
\text { what (thing) }\end{array}$ & $\begin{array}{l}\text { tsakem } \\
\text { that (thing) }\end{array}$ & $\begin{array}{l}\text { 'uo } \\
\text { something }\end{array}$ & $\begin{array}{l}\text { fra'u } \\
\text { everything }\end{array}$ & $\begin{array}{l}\text { ke'u } \\
\text { nothing }\end{array}$ \\
\hline $\begin{array}{c}\text { Tempus } \\
(\mathrm{E})\end{array}$ & $\begin{array}{l}\text { pehrr, krrpe } \\
\text { when }\end{array}$ & $\begin{array}{l}\text { tsakrr } \\
\text { then }\end{array}$ & $\begin{array}{l}\text { krro krro } \\
\text { sometime }\end{array}$ & $\begin{array}{l}\text { frakrr } \\
\text { always }\end{array}$ & $\begin{array}{l}\text { kawkrr } \\
\text { never }\end{array}$ \\
\hline $\begin{array}{c}\text { Modus } \\
(\mathrm{E})\end{array}$ & $\begin{array}{l}\text { pefya, fyape } \\
\text { how }\end{array}$ & $\begin{array}{l}\text { tsafya } \\
\text { in that way }\end{array}$ & $\begin{array}{l}\text { fyao } \\
\text { in some } \\
\text { way }\end{array}$ & $\begin{array}{l}\text { ? } \\
\text { in every } \\
\text { way }\end{array}$ & $\begin{array}{l}\text { ? } \\
\text { in no way }\end{array}$ \\
\hline $\begin{array}{c}\text { Locus } \\
\text { (E) }\end{array}$ & $\begin{array}{l}\text { peseng, tsengpe } \\
\text { where }\end{array}$ & $\begin{array}{l}\text { tsatseng } \\
\text { there }\end{array}$ & $\begin{array}{l}\text { tsengo } \\
\text { somewhere }\end{array}$ & $\begin{array}{l}\text { fratseng } \\
\text { everywhere }\end{array}$ & $\begin{array}{l}\text { kawtseng } \\
\text { nowhere }\end{array}$ \\
\hline
\end{tabular}

In conclusion, the strategy in planning $\mathrm{Na}$ 'vi is somehow the 
reverse compared to the one used in planning Klingon: in Klingon, the rigid but clear morphology is not intuitive, but syntax is highly regular, without notable exceptions; on the contrary, in Na'vi, while syntax is very rich and complex in many parts - so full of details so that is not always clear-morphology is highly regular, productive, also showing a lot of freedom-in fact, most particles can be prepositions and postpositions indifferently. The fact that Klingon and $\mathrm{Na}$ 'vi are fictional instead of auxiliary languages does not influence the degree of regularity in correlatives, which are highly irregular in Klingon and on the contrary very regular in Na'vi.

\section{Conclusions}

The comparison between natural and planned languages shows that correlatives are a tricky part for every language planner: in some cases, natural languages are even more regular than planned languages, even in the ones which claim regularity as the main important parameter in planning.

Moreover, after Esperanto, correlatives were often presented as an apart category in grammars: when this happens, correlatives tend to show a considerable level of regularity.

In conclusion, it can be said that planning a language-for whatever purpose - is not an easy task: the language planner should not only master the natural languages to be used as sources, but also he or she needs to understand the structural principles that underlie their grammars. This is particularly true in the case of correlatives.

\section{References}

Alfandari, A. 1961. Cours Pratique de Néo. Brussels: Éditions Brepols. 
Annis, W. 2011. Horen Lì'fyayä leNa'vi. A Reference Grammar of Na'vi.1.14. May 10. Retrieved July 19, 2011. Available at URL $<$ www.learnnavi.org $>$.

Bausani, A. 1974. Le lingue inventate: linguaggi artificiali, linguaggi segreti, linguaggi universali. Rome: Astrolabio Ubaldini.

Berger, R. 1949. Curse de Occidental (Interlingue). Berlin: Occidental-Buró. Adapted by S. Hartwig.

Blanke, D. 1985. Internationale Plansprachen. Berlin: Akademie Verlag.

Collison, W. \& A. Morris. 1937. Indication: A Study of Demonstratives, Articles, and Other 'Indicaters.' Language Monograph 17, 5128.

Comrie, B. 1989. Language Universals and Linguistic Typology. Chicago, IL: University of Chicago. . 1996. Natural and Artificial International Languages: A Typologist's Assessment. Journal of Universal Language 1.1, 35-55.

Couturat, L. \& L. Leau. 1903. Histoire de la langue universelle. Paris: Hachette.

de Wahl, E. 1928. Li direction nu secuend. Cosmoglotta 54, 165169. . 1929. International o Romanic. Cosmoglotta 57, 27-33.

Forster, P. 1982. The Esperanto Movement. The Hague: Mouton.

Frank, H. \& G. Lobin. 1997. Sprachorientierungsunterricht. LingvoOrientiga Instruado. Berlin \& Paderborn: Institut für Kybernetik Verlag.

Frommer, P. 2009. Some Highlights of Na'vi. Language Log 19

Dec. $<$ http://languagelog.ldc.upenn.edu/nll/?p=1977>.

Giacomelli, R. 2006. Lo strano caso della signora Hélène Smith. Milan: Scheiwiller.

Gledhill, C. 2000. The Grammar of Esperanto: A Corpus-Based Description. München: Lincom Europa. 
Gobbo, F. 1998. Verbigerazione fantastica. Italiano \& Oltre 3.4, 151-154.

. 2005a. The Digital Way to Spread Conlangs. In S. Posteguillo et al. (eds.), Language at Work: Language Learning, Discourse, and Translation Studies in Internet 4553. Castellon: Publicacions de la Universitat Jaume I. . 2005b. The European Union's Need for an International Auxiliary Language. Journal of Universal Language 6.1, 1-28. . 2008. Planning Languages and Language Planning: The

Contribution of Interlinguistics to Cross-Cultural Communication. In F. Boers et al. (eds.), Multilingualism \& Applied Comparative Linguistics I 24-60. Newcastle upon Tyne: Cambridge Scholars Publishing. . 2009. Fondamenti di interlinguistica ed esperantologia. Milan: Raffaello Cortina Editore.

Gobbo, F. \& M. Benini. 2011. Constructive Adpositional Grammar.

Newcastle upon Tyne: Cambridge Scholars Publishing.

Gode, A. 1951. Interlingua-English Dictionary. New York: Storm Publishers.

Gode, A. \& H. Blair. 1951. Interlingua Grammar. New York: IALA. Golden, B. 1997. Conservation of the Heritage of Volapük. In H. Tonkin (ed.), Esperanto, Interlinguistics, and Planned Language. Lanham, MD: University Press of America.

Haas, F. 1956. Grammatica de Interlingue in Interlingue. Winterthur: Interlingue-Servicie.

Haupenthal, R. 1988. La Esperantisto. Gazeto por la amikoj de la lingvo Esperanto 1889-1895. Hildesheim: Georg Olms Verlag.

Jespersen, O. 1929/2006. Otto Jepersen: An International Language. London: Routledge.

Kloczko, E. 2002. Lingue elfiche. Rome: Tre Editori. . 2004. Lingue degli Hobbit, dei Nani, degli Orchi. Rome: Tre Editori.

Künzli, A. 2010. L. Zamenhof (1859-1917). Esperanto, Hillelismus 
(Homaranismus) und die "Judische Frage" in Ost- und Westeuropa. Wiesbaden: Harassowitz Verlag.

Large, A. 1985. The Artificial Language Movement. Oxford \& New York: Blackwell.

Lehmann, W. 1952. Proto-Indo-European Phonology. Austin, TX: University of Texas Press.

. 1974. Proto-Indo-European Syntax. Austin, TX: University of Texas Press.

Libert, A. 2008. Daughters of Esperanto. München: Lincom Europa.

Lindstedt, J. 2006. Native Esperanto as a Test Case for Natural Language. SKY Journal of Linguistics 19, 47-55.

Lyons, J. 1991. Natural Language and Universal Grammar I. Cambridge: Cambridge University Press. . 1981. Language and Linguistics: An Introduction. Cambridge: Cambridge University Press.

Maxwell, D. 1988. On the Acquisition of Esperanto. Studies in Second Language Acquisition 10, 51-61.

Miller, M. \& C. Scheideman. 2011. Na'vi-English Dictionary (ver. 12.261). Last Update: July 16. Retrieved July 19. Available at URL <www.learnnavi.org>.

Noel, R. 1980. The Languages of Tolkien's Middle-Earth. New York: Mariner Books.

Okrand, M. 1992. The Klingon Dictionary. Addendum Edition. New York: Pocket Books.

Pennacchietti, F. 1987. L'internazionalità dell'esperanto e il carattere degli elementi indoeuropei in esso. In A. Chiti-Batelli (ed.), La comunicazione internazionale tra politica e glottodidattica 130-139. Milano: Marzorati.

Poška, A. 1981. Litovajoj en la Esperanto-Gramatiko. Interlingvistiko Esperantologio 85. Sofia: Bulgara Esperantista Asocio.

Schubert, K. 1989. Interlinguistics - its Aims, its Achievements, and its Place in Language Science. In K. Schubert (ed.), Interlinguistics: Aspects of the Science of Planned Language 249-274. 
Berlin \& New York: Mouton de Gruyter.

Solopova, E. 2009. Languages, Myths, and History: An Introduction to the Linguistic and Literary Background of J. Tolkien's Fiction. New York: North Landing Books.

Szerdahelyi, I. 1989. Eszperantó. Bevezetés és nyelvgyakorlatok. Budapest: Tankönyvkiadó.

Tesnière, L. 1959. Eléments de syntaxe structurale. Paris: Kliencksiek.

Tomasello, M. 2003. Constructing a Language: A Usage-Based Theory of Language Acquisition. Cambridge, MA \& London: Harvard University Press.

Tresoldi, R. 2011. L'influenza del Volapük di Schleyer su Zamenhof (1879-1887). La influo de la Volapuko de Schleyer sur Zamenhof (1879-1887). InKoj. Interlingvistikaj Kajeroj 2, 112-141.

Waringhien, G. 1959. Lingvo kaj vivo. La Laguna de Tenerife: Stafeto.

Wells, J. 2010. English Esperanto English Dictionary. New York: Mondial.

Whorf, B. 1945. Grammatical Categories. Language 21.1, 1-11.

Yaguello, M. 2001. Lunatic Lovers of Language: Imaginary Languages and their Inventors. London: Athlone Press. 